\title{
Nucleic acid recovery from thyroid fine-needle cytology slides
}

\author{
Ácidos nucleicos extraídos de lâminas com citologia \\ de punção de agulha fina de tiroide
}

Kelly Cristina Saito', Cesar Seigi Fuziwara', Edna Teruko Kimura'

${ }^{1}$ Department of Cell and Developmental Biology, Institute of Biomedical Sciences, Universidade de São Paulo (USP), São Paulo, SP, Brazil
Correspondence to Edna Teruko Kimura Av. Prof. Lineu Prestes, 1524, sala 414 Instituto de Ciências Biomédicas, Universidade de São Paulo 05508-900 - São Paulo, SP, Brazil etkimura@usp.br

Received on Apr/1/2013 Accepted on Jun/6/2013
M uch interest has been focused in nucleic acid isolation from tissue samples stored for long periods and their utilization on molecular biomarkers research. However, sample fixation induces chemical modifications in macromolecules (1) that result in a laborious and difficult protocol to extract nucleic acid for molecular analysis. In this context, the article recently published by Kizys and cols. (2) contributed to show efficient methods of nucleic acid recovery from archived formalin-fixed/ paraffin-embedded (FFPE) and fine-needle aspiration (FNA) samples of thyroid tissue.

Despite the efforts, the issue that remains a challenge in the most effective protocols is to obtain better yield and quality of DNA/RNA due to the damaging effect of the fixation process, particularly for RNA analysis. In contrast with the difficulty in obtaining conserved messenger RNA from archived samples, the fraction of microRNA (miRNA) is less affected by fixation and storage time $(3,4)$. Mature miRNA is a single-stranded noncoding small RNA of $~ 19-22$ nucleotide length that regulates gene expression at the post-transcriptional level (5). These molecules pair to 3'UTRs of target mRNA and thereby cause their silencing or degradation. The miRNA might be a promising prognostic and diagnostic biomarker for thyroid cancer (6).

In this context, we have performed, in archived FNA-stained slides, the analysis of BRAFT1799A mutation (7) along with miRNAs expression, miR-146b (8) and let7-f (9), which were modulated in papillary thyroid carcinoma (PTC) $(10,11)$. The acid guanidinium thiocyanate-phenol-chloroform method (12) using $\mathrm{TRIzol}^{\mathrm{TM}}$ enabled the RNA/DNA co-isolation from the same archived FNA, despite the reduced number of cells in the cytological slides. From the extracted RNA, we performed real-time PCR to amplify miRNA, and observed high expression of miR-146b in PTC compared with goiter (normalized expression $m i R-146 b / R N U 6 B$ : PTC $21.55 \pm 5.83^{*}$ vs. goiter $0.18 \pm 0.06$, ${ }^{*} \mathrm{P}<0.05$ ), and no change in let7-f expression (normalized expression let7-f /RNU6B: PTC $0.30 \pm 0.13$ vs. goiter $0.07 \pm 0.02$, ns). In addition, DNA obtained was suitable for $B R A F$ mutation analysis by RFLP-PCR (Restriction Fragment Length Polymorphism -PCR) in all FNA slides tested.

Using this approach, we observed that it is possible to access both nucleic acids, RNA and DNA, from the same archived thyroid FNA-stained slide. Furthermore, DNA was adequate to perform mutation analysis, and the quality of total RNA and its amount was satisfactory to investigate several miRNAs from the same sample. In conclusion, this procedure could be useful in detecting molecular biomarkers and drawing correlations with cytological analysis, which might improve the accuracy of FNA as a diagnostic tool of thyroid nodule. 
Acknowledgments: this study was supported by grants \#2010/51704-0 and \#2011/50732-2 from Fundação de Amparo à Pesquisa do Estado de São Paulo (Fapesp), Conselho Nacional de Desenvolvimento Científico e Tecnológico (CNPq), Coordenação de Aperfeiçoamento de Pessoal de Nível Superior (Capes), and Pró-Reitoria de Pesquisa da Universidade de São Paulo (NapMiR).

Disclosure: no potential conflict of interest relevant to this article was reported.

\section{REFERENCES}

1. Klopfleisch R, Weiss AT, Gruber AD. Excavation of a buried treasure--DNA, mRNA, miRNA and protein analysis in formalin fixed, paraffin embedded tissues. Histol Histopathol. 2011;26(6):797810.

2. Kizys MM, Cardoso MG, Lindsey SC, Harada MY, Soares FA, Melo $\mathrm{MC}$, et al. Optimizing nucleic acid extraction from thyroid fineneedle aspiration cells in stained slides, formalin-fixed/paraffinembedded tissues, and long-term stored blood samples. Arq Bras Endocrinol Metabol. 2012;56(9):618-26.

3. Li J, Smyth P, Flavin R, Cahill S, Denning K, Aherne S, et al. Comparison of miRNA expression patterns using total RNA extracted from matched samples of formalin-fixed paraffin-embedded (FFPE) cells and snap frozen cells. BMC Biotechnol. 2007;7:36.

4. Kolbert CP, Feddersen RM, Rakhshan F, Grill DE, Simon G, Middha $\mathrm{S}$, et al. Multi-platform analysis of MicroRNA expression mea- surements in RNA from fresh frozen and FFPE tissues. PLoS One. 2013;8(1):e52517.

5. Ricarte Filho JC, Kimura ET. [MicroRNAs: novel class of gene regulators involved in endocrine function and cancer]. Arq Bras Endocrinol Metabol. 2006;50(6):1102-7.

6. Ferraz $C$, Eszlinger M, Paschke R. Current state and future perspective of molecular diagnosis of fine-needle aspiration biopsy of thyroid nodules. J Clin Endocrinol Metab. 2011;96(7):2016-26.

7. Kimura ET, Nikiforova MN, Zhu Z, Knauf JA, Nikiforov YE, Fagin JA. High prevalence of BRAF mutations in thyroid cancer: genetic evidence for constitutive activation of the RET/PTC-RAS-BRAF signaling pathway in papillary thyroid carcinoma. Cancer Res. 2003;63(7):1454-7.

8. Geraldo MV, Yamashita AS, Kimura ET. MicroRNA miR-146b-5p regulates signal transduction of TGF-beta by repressing SMAD4 in thyroid cancer. Oncogene. 2012;31(15):1910-22.

9. Ricarte-Filho JC, Fuziwara CS, Yamashita AS, Rezende E, daSilva MJ, Kimura ET. Effects of let-7 microRNA on cell growth and differentiation of papillary thyroid cancer. Transl Oncol. 2009;2(4):236-41.

10. Geraldo MV, Fuziwara CS, Friguglieti CU, Costa RB, Kulcsar MA, Yamashita AS, et al. MicroRNAs miR-146-5p and let-7f as prognostic tools for aggressive papillary thyroid carcinoma: a case report. Arq Bras Endocrinol Metabol. 2012;56(8):552-7.

11. Pallante P, Visone $R$, Croce $C M$, Fusco A. Deregulation of microRNA expression in follicular-cell-derived human thyroid carcinomas. Endocr Relat Cancer. 2010;17(1):F91-104.

12. Chomczynski P, Sacchi N. Single-step method of RNA isolation by acid guanidinium thiocyanate-phenol-chloroform extraction. Anal Biochem. 1987;162(1):156-9. 